\title{
Analysis Of Truck Trips From Ahmedabad To Tami Nadu And Morbi To Tamil Nadu
}

\author{
Jaykumar Chettiar ${ }^{1}$, Dr. H. R. Varia ${ }^{2}$, Deep Patel ${ }^{3}$ \\ MTech. Student, Department of Civil Engineering, T.I.T.S Modasa, Gujarat, India ${ }^{1}$ \\ Professor and Head, Department of Civil Engineering, A.I.I.E Ahmedabad, Gujarat India ${ }^{2}$ \\ Professor, Department of Civil Engineering, S.I.T.E.R, Ahmedabad, Gujarat, India ${ }^{3}$ \\ Email: jkchettiar844@gmail.com ${ }^{1}$,hr7varia@yahoo.co.in ${ }^{2}$,pateldeep5963@yahoo.com ${ }^{3}$
}

\begin{abstract}
India is a developing Asian country. Freight Transportation is very important for development of nation. Generally, Freight Transportation on highway is carried out by trucks. Ahmedabad and Morbi are considered as a study area where the trucks trips are originated for transportation in various regions. Different types of goods and loads are transported from origin to destinations. In this thesis Tamil Nadu is considered as the Destination of this trips generated. Detailed Questionnaire interview survey were carried in various south Indian transport of Ahmedabad and Morbi. Interview from the system operator of the trucks were also carried. 1000s of trucks are travelling from these two sources to destinations every annum. Various data are collected from these interviews. From the collected data, origins to destinations matrices have been developed. Truck trips are assigned on the routes, desire line diagram of truck trips is prepared and truck trip classification is also carried out according to commodity type. Analysis are also carried out from the collected data.
\end{abstract}

\section{Index Terms-Trip Generation, Truck, Trip Analysis.}

\section{INTRODUCTION}

Road transport is vital to the economic development and social integration of the country. Easy accessibility, flexibility of operations, doorto-door service and reliability have earned road transport an increasingly higher share of both passenger and freight traffic vis-à-vis other transport modes. In addition to these factors, transit time, availability of capacity on alternate modes, quality and reliability of the service, associated costs like warehousing and demurrage, etc., all influence the choice of the mode of transport.

Freight traffic carried by road and rail increased from 257 billion tone $\mathrm{km}$ in 1980-81 to 2053 billion tone $\mathrm{km}$ in 2011-12. While the increase in freight movement is impressive, more striking is the changing modal composition. Rail had historically dominated freight traffic, carrying about 60 percent of freight in the early 1980s (Figure 1.2), but it came down to about 50 percent by the late 1980s.

\subsection{Aim Of Study}

The main aim of this study is to develop a truck trip generation model for the trucks travelling from Ahmedabad and Morbi to Tamil Nadu and to analyse truck trips enrooted between AhmedabadTamil Nadu and Morbi-Tamil Nadu by considering various parameters, to identify various problems facing by truck industries for the route of Ahmedabad-Tamil Nadu and Morbi-Tamil Nadu.

\subsection{Objective Of Study}

- To analyse truck trips enrooted between Ahmedabad-Tamil Nadu and Morbi-Tamil Nadu by considering various parameters.

- To identify various problems facing by truck industries for the route of
Ahmedabad-Tamil Nadu and Morbi-Tamil Nadu.

\section{LITERATURE REVIEW}

Tomasz Kulpa in 2014 studied Freight truck trip generation is a crucial part of a 4-stage model, especially in regional freight model development. Data needed to construct trip generation equations are usually gathered at company level using the trip diary. Although this approach seems to be most suitable it may not cover all trips made by freight vehicles in analysed area. In this paper, it was shown that empirical values of trip generations for modelling purposes can be obtained not necessary from questionnaires in transport companies. Of course, this gives general overview on truck usage, but still does not give information about all trucks if is conducted on small area. Thus, wider truck survey like TIUS (Truck Inventory and Usage Survey) made in USA should be conducted in Polish condition. This kind of survey should answer questions about garaging places as well as daily truck trips. On the other hand, for specified area, trip generations may be calculated using calibrated O-D matrix.

Joubert and Meintjes in 2016 studied this paper a method of generating synthetic freight populations using a complex network was proposed. It was generally found that the start times of the synthetic activity chains followed the same distribution as the observed activity chains, albeit sometimes underestimated. The number of activities in the activity chains of the synthetic populations correspond to that of the observed activity chains. The complex network approach of generating synthetic freight populations is indeed a 


\section{Available online at www.ijrat.org}

novel approach, and can be used in simulation models to accurately represent freight populations.

\section{METHODOLOGY}

Methodology has been adopted to collect various data from primary data collection and secondary data collection where primary collection consists of Questionary survey from transporters and personal interview survey whereas secondary survey consists of google maps. After Data collection processes collected data are entered in a excel sheet for analyse where analysis are carried out and various results is been taken.

\section{STUDY AREA}

In this study Ahmedabad and Morbi are considered as source whereas Tamil Nadu is considered as its destination. The one-way trip from Ahmedabad Tamil Nadu and Morbi Tamil Nadu is considered in this study. The Distance travelled between these two junctions are also considered as study area. There are total 8 Checkposts in these trips (Songadh, Navapur, Pandripur, Jalgi, Nelamangalam, Atthipalli, Hossur, Thopur), but recently the organization rules and system has been changed and all the checkposts are closed. There are total 24 toll plaza for travel between Ahmedabad and Coimbatore and it changes for all other districts of Tamil Nadu.

Ahmedabad is the largest city and former capital of the Indian state of Gujarat Ahmedabad is the sixth largest city (Area wise) in the country. It is fast developing city because of which many industries such as GIDC of Vatva and Naroda. It is economic center for agricultural export, at both the provincial and national levels. Many industries are available in Ahmedabad such as submersible pumps units, non-woven fabric mill, pin maker mill, textile weaving factory, agricultural industry, biscuits factory, flour mill. Textile weaving factory are been transported in various district of Tamil Nadu. The percentage of different goods which is been transported from Ahmedabad to Tamil Nadu.

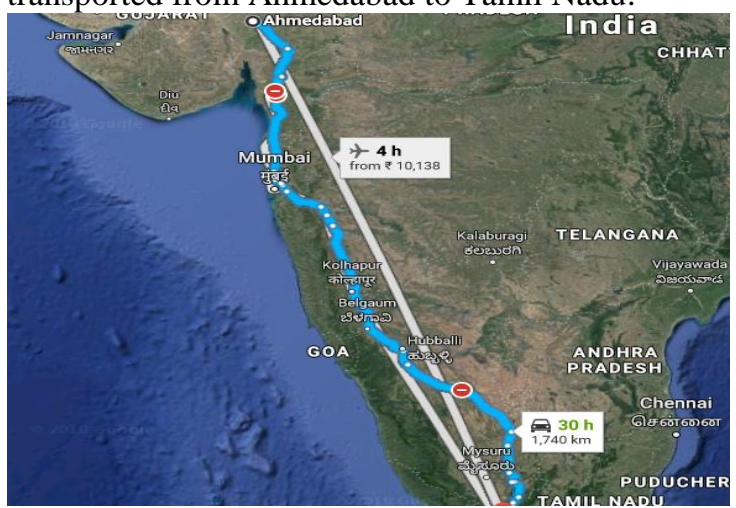

Figure 1: Route Map Satellite Ahmedabad to Coimbatore@ Google Maps.

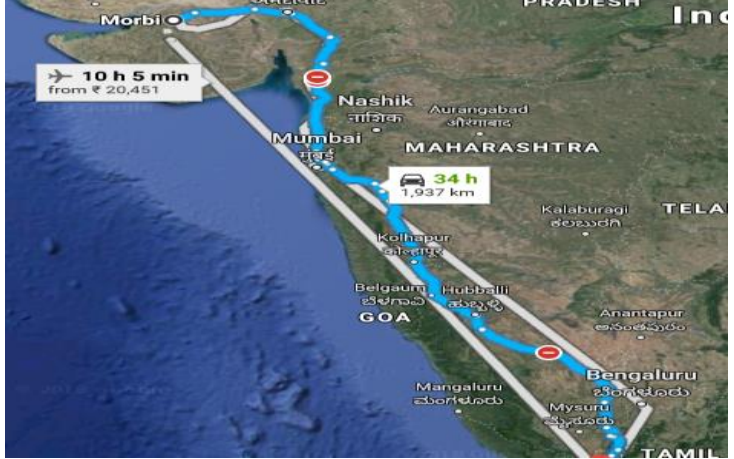

Figure 2: Route Map Satellite Morbi to Coimbatore @ google maps

\section{DATA COLLECTION AND ANALYSIS}

For the proposed study required data are collected as per. Questionary survey with transporters and personal interview with truck operator has been carried out for primary data and for secondary data google maps.

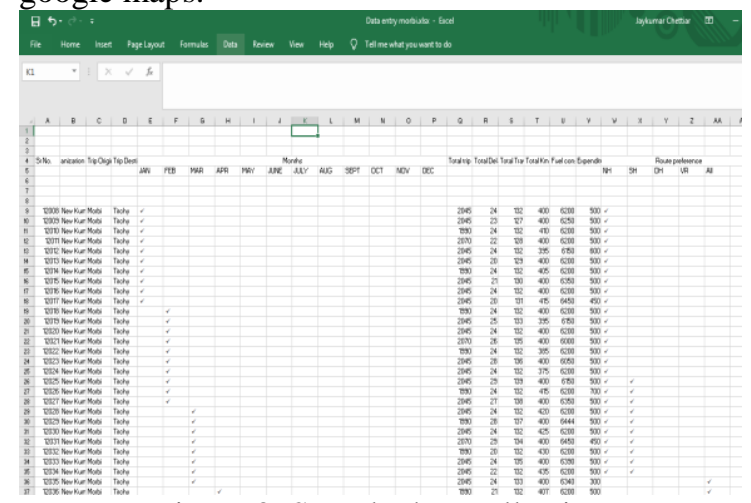

Figure 3: Sample data collection

5.1 Time series Analysis for total Number of trips

Table 1: Time series statistics of total number of trips

\begin{tabular}{|c|c|c|}
\hline \multirow{2}{*}{ Years } & \multicolumn{2}{|c|}{ Number of trips } \\
\cline { 2 - 3 } & Ahmedabad & Morbi \\
\hline $\mathbf{2 0 1 3}$ & 13112 & 7096 \\
\hline $\mathbf{2 0 1 4}$ & 13156 & 7130 \\
\hline $\mathbf{2 0 1 5}$ & 12795 & 6546 \\
\hline $\mathbf{2 0 1 6}$ & 10096 & 4547 \\
\hline $\mathbf{2 0 1 7}$ & 10198 & 4856 \\
\hline $\mathbf{2 0 1 8}$ & 12006 & 5130 \\
\hline
\end{tabular}

Figure 4: Year wise statistics of total number of trips 
International Journal of Research in Advent Technology, Vol.5, No.1, January 2017 E-ISSN: 2321-9637

Available online at www.ijrat.org

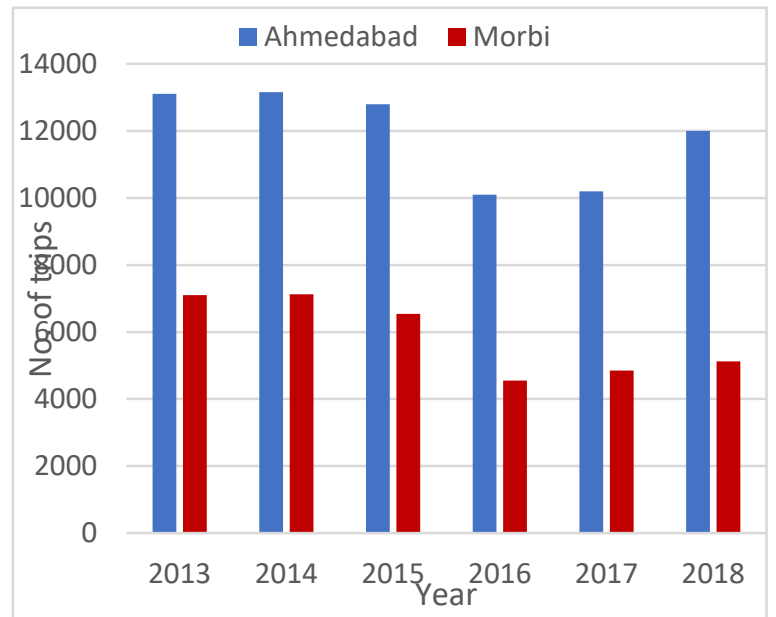

- Ahmedabad

Morbi
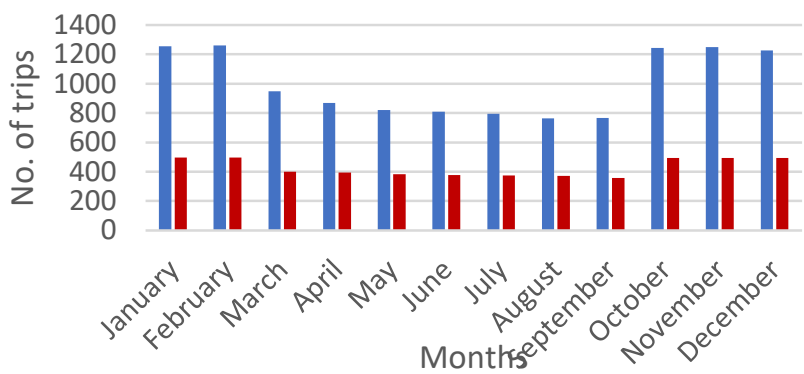

\subsection{Month wise trips for base year}

Table 2: Month wise trips of total number of trips for base year

\begin{tabular}{|c|c|c|}
\hline \multirow{2}{*}{ Month } & \multicolumn{2}{|c|}{ Number of trips } \\
\cline { 2 - 3 } & Ahmedabad & Morbi \\
\hline January & 1254 & 497 \\
\hline February & 1261 & 496 \\
\hline March & 949 & 399 \\
\hline April & 870 & 393 \\
\hline May & 820 & 382 \\
\hline June & 809 & 377 \\
\hline July & 796 & 375 \\
\hline August & 764 & 372 \\
\hline September & 765 & 356 \\
\hline October & 1243 & 495 \\
\hline November & 1249 & 495 \\
\hline December & 1227 & 494 \\
\hline
\end{tabular}

Figure 5: Month wise statistics of total no of trips for base year in Ahmedabad and Morbi.
5.3 Trips based on different types of goods

Table 3: Number of trips for different types of goods

\begin{tabular}{|c|c|c|}
\hline \multirow{2}{*}{ Types of goods } & \multicolumn{2}{|c|}{ Number of trips } \\
\cline { 2 - 3 } & Ahmedabad & Morbi \\
\hline Agriculture & 3704 & 10 \\
\hline Ceramic & 1327 & 5000 \\
\hline Powder & 1978 & 90 \\
\hline Chemical & 2674 & 20 \\
\hline Equipment & 5180 & 10 \\
\hline
\end{tabular}

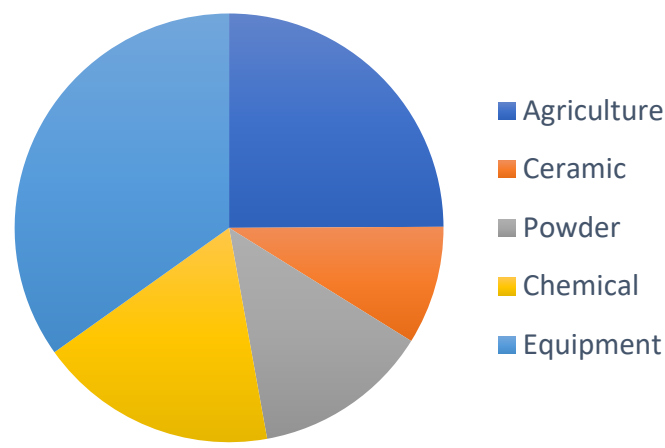

Figure 6: Frame of truck transportation for different types of goods (Ahmedabad)

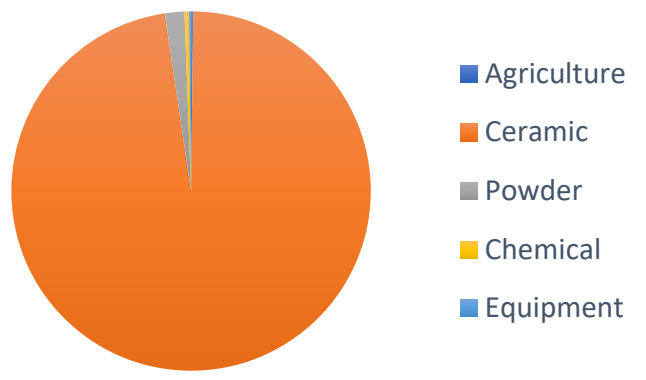

Figure 7: Frame of truck transportation for different types of goods (Morbi)

\subsection{Trips based vehicle types}

Table 4: No of trips for types of vehicles

\begin{tabular}{|c|c|c|}
\hline \multirow{2}{*}{$\begin{array}{c}\text { Type of } \\
\text { vehicle }\end{array}$} & \multicolumn{2}{|c|}{ Number of trips } \\
\cline { 2 - 3 } & Ahmedabad & Morbi \\
\hline $16 \mathrm{~T}$ & 1544 & 666 \\
\hline $21 \mathrm{~T}$ & 4198 & 2130 \\
\hline $25 \mathrm{~T}$ & 6275 & 2332 \\
\hline
\end{tabular}

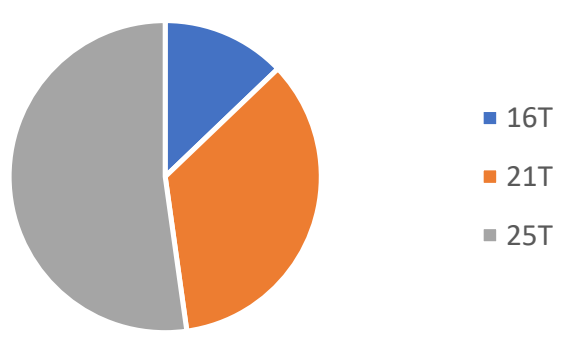

Figure 8: Frame for truck transportation of types of vehicle (Ahmedabad) 

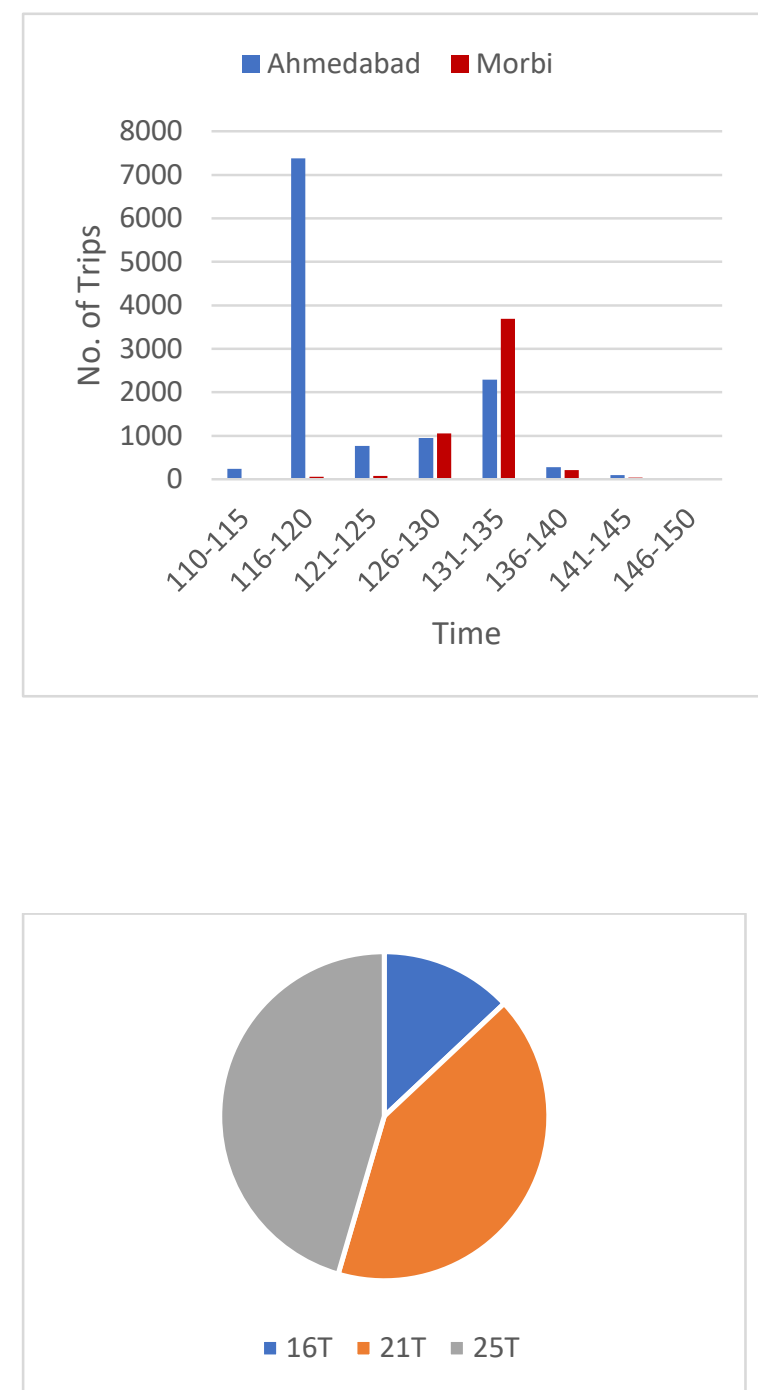

Figure 9: Frame for truck transportation of types of vehicle (Morbi)

5.5 Trips based on Total travel time

Table 6: Number of Trips according to total travel time

\begin{tabular}{|l|l|l|}
\hline \multirow{2}{*}{$\begin{array}{l}\text { Total Travel } \\
\text { Time(hrs) }\end{array}$} & \multicolumn{2}{|c|}{ Number of trips } \\
\cline { 2 - 3 } & Ahmedabad & Morbi \\
\hline $\mathbf{1 1 0 - 1 1 5}$ & 241 & 4 \\
\hline $\mathbf{1 1 6 - 1 2 0}$ & 7378 & 60 \\
\hline $\mathbf{1 2 1 - 1 2 5}$ & 762 & 79 \\
\hline $\mathbf{1 2 6 - 1 3 0}$ & 946 & 1056 \\
\hline $\mathbf{1 3 1 - 1 3 5}$ & 2286 & 3691 \\
\hline $\mathbf{1 3 6 - 1 4 0}$ & 281 & 207 \\
\hline $\mathbf{1 4 1 - 1 4 5}$ & 98 & 33 \\
\hline $\mathbf{1 4 6 - 1 5 0}$ & 15 & 0 \\
\hline
\end{tabular}

Figure 10: Statistics of trip according to total travel time of Ahmedabad and Morbi
6. FINDING FROM THE STUDY

- Reduction in total trips observed for duration of 2016 \& 2017 year due to reduction in production due to implementation of GST.

- Maximum trips are observed during February month from both origins and the reason is clearance of stock at reasonable rate due to ending of financial year.

- Most of the trips are attracted at west Tamilnadu.

- Minimum trip distance lies between 1551 $\mathrm{km}-1600 \mathrm{~km}$ and maximum trip distance lies between $2301 \mathrm{~km}-2350 \mathrm{~km}$.

- Minimum trip time lies between $110 \mathrm{hrs.-}$ $115 \mathrm{hrs}$. whereas maximum trip time lies between $146 \mathrm{hrs}$. $-150 \mathrm{hrs}$.

- Maximum trips observed from Ahmedabad are carrying equipment's and from Morbi maximum trips are for ceramic products.

- The gradual increase in trips observed with increase in load carrying capacity from both origins.

- Most of the trips are preferring NH more followed by SH, DR \& VR.

\section{ACKNOWLEDGEMENT}

I would like to express my sincere gratitude to Dr. H. R. Varia and Mr. Deep patel for initial spark and subsequent valuable guidance in my research work. My special gratitude to my classmates for their meaningful support for their kind helps at different levels. Special thanks to my college for giving me the valuable knowledge. Above all I am thankful to almighty God for everything.

\section{REFERENCES}

[1] Pania and K. Sahua, "Modelling urban freight generation: A case study of seven cities in Kerala", India Transport Policy 69 (2018) 49-64.

[2] A. Amavi and P. Romero, "Advanced trip generation/attraction models", Procedia - Social and Behavioral Sciences 160 (2014) 430 - 439.

[3] Dr. Berki, Dr. habil and Janos Monigl, "Trip generation and distribution modelling in Budapest", Transportation Research Procedia 27 (2017) 172-179.

[4] F. Toilier, M. Gardrat, J.L. Routhier and A. Bonnafous, "Freight transport modelling in urban areas: the French case of the FRETURB model", Case Studies on Transport Policy.

[5] Sánchez-Díaz, "modelling urban freight generation: A study of commercial 
Available online at www.ijrat.org

establishments' freight needs", Transportation Research Part A.

[6] W. Joubert and Meintjes, "Freight activity chain generation using complex networks of connectivity", Transportation Research Procedia 12 (2016) 425 - 435.

[7] Sillaparcharn, "vehicle ownership and trip generation modelling - a case study of Thailand" Transportation Research.

[8] Jansuwan, Ryu and Chen, "A two-stage approach for estimating a state-wide truck trip table", Transportation Research. 